\title{
The effects of fructose and phosphate infusions on dry matter intake of lactating cows
}

\author{
Roni Yair and Michael S. Allen ${ }^{1}$ \\ Department of Animal Science, Michigan State University, East Lansing 48824-1225
}

\begin{abstract}
The objective of this study was to examine the effects of fructose and phosphate $(\mathrm{Pi})$ infusions on dry matter intake by dairy cows to further understand the mechanisms controlling feed intake related to hepatic energy status. We performed 3 experiments in which we infused fructose and Pi intravenously or abomasally to Holstein cows. The first experiment used 8 cows (4-8 d postpartum) in a duplicated $4 \times 4$ Latin square experiment with 1 square of multiparous and 1 square of primiparous cows. A $2 \times 2$ factorial arrangement of treatments was used including jugular infusions of solutions $(1 \mathrm{~L} / \mathrm{h})$ containing fructose or glucose $(0.6$ $\mathrm{mol} / \mathrm{h})$ and $\mathrm{Pi}\left(\mathrm{NaH}_{2} \mathrm{PO}_{4}\right)$ or $\mathrm{NaCl}(0.3 \mathrm{~mol} / \mathrm{h})$. Periods were $24 \mathrm{~h}$, including $2 \mathrm{~h}$ for infusions and $22 \mathrm{~h}$ for recovery. The second experiment used 4 multiparous cows (74-81 d postpartum) in a $4 \times 4$ Latin square design and infused fructose or glucose and either Pi or no $\mathrm{Pi}$ at the same rates as experiment 1 . Periods were $24 \mathrm{~h}$, including $1 \mathrm{~h}$ for infusions and $23 \mathrm{~h}$ for recovery. The third experiment used 4 ruminally cannulated multiparous cows (15-26 d postpartum) in a $4 \times 4$ Latin square design and infused fructose or glucose and either $\mathrm{Pi}$ or $\mathrm{NaCl}$ at the same rates as experiment 1 but to the abomasum. Periods were $24 \mathrm{~h}$, including $1 \mathrm{~h}$ for infusions and $23 \mathrm{~h}$ for recovery. In each experiment, feed intake was recorded by a computerized data acquisition system; blood was analyzed for the concentrations of glucose, nonesterified fatty acids, and $\mathrm{Pi}$; and the liver was analyzed for the concentration of $\mathrm{Pi}$ (experiments 2 and 3 only). Overall, fructose infusion increased DMI by fresh cows when infused intravenously and abomasally, but it did not affect DMI by mid-lactation cows. Fructose infusion also reduced hepatic $\mathrm{Pi}$, and $\mathrm{Pi}$ infusion increased hepatic Pi when infused abomasally but not intravenously. These results suggest that fructose increases feed intake, likely by sequestering $\mathrm{Pi}$ and preventing ATP production. When infused intravenously
\end{abstract}

\footnotetext{
Received October 17, 2016.

Accepted December 3, 2016.

${ }^{1}$ Corresponding author: allenm@msu.edu
}

to multiparous cows, Pi increased DMI and did not affect hepatic Pi content. However, when infused abomasally, Pi reduced DMI and increased hepatic Pi content. These results suggest that although $\mathrm{Pi}$ infusion prevents the effect of fructose loading and reduces DMI, it also increases intake through a competing mechanism. Examining long-term effect of Pi infusion on DMI could determine if competing mechanisms complicate the determination of $\mathrm{P}$ requirement for dairy cows. These results are consistent with the control of feed intake by hepatic energy status in dairy cows.

Key words: control of feed intake, hepatic oxidation theory, ATP, energy charge

\section{INTRODUCTION}

The control of energy intake in dairy cows is complex, including mechanisms that act independently (e.g., distention, osmotic effects) as well as many interacting factors that affect feed intake via their effects on metabolism (Ingvartsen and Andersen, 2000; Allen, 2014).

Moreover, the control of intake changes during the lactation cycle. A growing consensus exists that during the critical first few weeks of lactation, when cows are in negative energy balance because milk energy output greatly exceeds energy intake, the control of feed intake is dominated by fuel-based sensing mechanisms, specifically hepatic oxidation of fuels (Allen et al., 2009; Schäff et al., 2012; Derno et al., 2013; Martineau et al., 2016) and not by gut fill (Allen et al., 2009). Afterward, in the following months, distention by undigested feed residues in the gastrointestinal tract likely dominates the control of feed intake as milk yield and nutrient requirements are high (Allen, 1996).

Research in nonruminants revealed the effect of oxidation of fuels on feed intake by showing that inhibition of fuel oxidation stimulates feed intake and stimulation of oxidation inhibits feed intake; the research also showed that the signal to brain feeding centers is via hepatic vagal afferents (Langhans, 1996). Control of feed intake in nonruminants was demonstrated to be related to hepatic energy status, which is determined by the balance between the rates of production and utiliza- 
tion of ATP (Friedman et al., 1999). Fructose loading results in the accumulation of fructose 1-phosphate in mammalian livers (Kjerulf-Jensen, 1942), temporarily sequestering phosphate $(\mathbf{P i})$. Perfusion of the liver of rats with fructose rapidly ( $<10 \mathrm{~min}$ ) decreased hepatic ATP content by $77 \%$ with a transient decrease in $\mathrm{Pi}$ (Woods et al., 1970). Fructose has a similar effect of reducing available $\mathrm{Pi}$ and $\mathrm{ATP}$ content in the rat and human liver (Woods et al., 1970; Morris et al., 1978; Abdelmalek et al., 2012), and fructose has elicited feeding in rabbits (Novin et al., 1991). The fructose analog 2,5-anhydro-D-mannitol (2,5-AM), which is phosphorylated but not metabolized further, decreased hepatic ATP content and elicited an eating response in rats (Tordoff et al., 1988; Rawson et al., 1994; Koch et al., 1998). The reduction in ATP content was likely from trapping $\mathrm{Pi}$ because $\mathrm{Pi}$ loading prevented the reduction in hepatic ATP content and stimulation of feeding by 2,5-AM (Rawson and Friedman, 1994). Therefore, fructose loading in the lactating cow might enable us to link hepatic ATP synthesis and feeding behavior, thus elucidating the mechanisms underlying control of feed intake by hepatic oxidation of fuels. We hypothesized that fructose will decrease hepatic ATP content, thus delaying satiety and increasing meal size and DMI, while Pi loading will attenuate its effects. Accordingly, the objective of this study was to examine the effects of fructose and $\mathrm{Pi}$ infusions on feeding behavior and metabolic responses of dairy cows.

\section{MATERIALS AND METHODS}

\section{Animal Housing and Care}

All experimental procedures were approved by the Institutional Animal Care and Use Committee at Michigan State University (East Lansing). For all experiments, cows were housed in tiestalls at the Michigan State University dairy facility, fed a TMR once daily at $1100 \mathrm{~h}$ at $120 \%$ of expected intake (their intake in the previous day), and milked twice daily in the milking parlor approximately at $500 \mathrm{~h}$ and $1600 \mathrm{~h}$. Feed offered and refused was recorded and sampled daily throughout the experiment for determination of nutrient content (Table 1). The amounts of feed offered and refused were weighed, and the feed offered was adjusted daily.

\section{Design and Treatments}

Experiment 1. Eight Holstein cows in the early postpartum (PP) period (4-8 d PP) were used in a duplicated $4 \times 4$ Latin square experiment balanced for carryover effects with 1 square of multiparous cows and
1 square of primiparous cows. Cows were offered the prepartum ration beginning $21 \mathrm{~d}$ prepartum and the lactation ration beginning at parturition and throughout the experiment (Table 1). All cows were fitted with a single jugular catheter (left or right jugular vein) 2 to $3 \mathrm{~d}$ before the beginning of the experiment. Catheter patency was checked daily until removal at the end of the experiment. Cows were randomly assigned to tiestalls and treatment sequences. Periods were $24 \mathrm{~h}$, beginning at the conditioned meal after feeding and including $2 \mathrm{~h}$ for infusions and $22 \mathrm{~h}$ for recovery. Cows were blocked from feed for $2 \mathrm{~h}$ before the beginning of each infusion. A $2 \times 2$ factorial arrangement of treatments was used, and treatments included jugular infusions $(1 \mathrm{~L} / \mathrm{h})$ of solutions containing fructose or glucose $(0.6 \mathrm{~mol} / \mathrm{h})$ and phosphate $\left(\mathrm{NaH}_{2} \mathrm{PO}_{4}\right)$ or $\mathrm{NaCl}(0.3$ $\mathrm{mol} / \mathrm{h}$ ). Glucose was used as the control for the fructose treatment because the two sugars have the same molecular mass and energy content and glucose uptake by the liver of mature bovines is negligible (Stangassinger and Giesecke, 1986). Sodium chloride was used as an osmotic control for the $\mathrm{Pi}$ treatment. The infusion rate for $\mathrm{Pi}$ was estimated based on the work of Rawson et al. (1994) with rats, which used about 2:1 ratio between

Table 1. Ingredient and nutrient composition (\% of DM unless otherwise noted) of the experimental diets

\begin{tabular}{lccc}
\hline & \multicolumn{3}{c}{ Experiment } \\
\cline { 2 - 4 } Item & 1 & 2 & 3 \\
\hline Ingredient & & & \\
Corn silage & 29.9 & 19.4 & 29.9 \\
Haylage & 15.1 & 16.6 & 15.1 \\
Alfalfa hay & 13.6 & - & 13.6 \\
Dry ground corn & 19.5 & 15.2 & 19.5 \\
Soybean meal & 16.4 & 8.7 & 16.4 \\
Soybean hulls & 4.2 & 7.0 & 4.2 \\
Cottonseeds & - & 7.6 & - \\
High-moisture corn & - & 15.6 & - \\
Wheat straw & - & 5.6 & - \\
Vitamin-mineral mix $1^{1}$ & 1.4 & - & 1.4 \\
Vitamin-mineral mix $2^{2}$ & - & 4.41 & - \\
Nutrient composition & & & \\
DM (\%) & 56.4 & 55.7 & 50.6 \\
Starch & 23.9 & 27.3 & 20.9 \\
NDF & 31.0 & 28.6 & 33.0 \\
CP & 17.6 & 16.9 & 17.6 \\
P & 0.39 & 0.36 & 0.39 \\
\hline
\end{tabular}

${ }^{1}$ Vitamin-mineral mix 1 contained (DM basis): $11.40-13.60 \% \mathrm{NaCl}$, $12.80-15.30 \% \mathrm{Ca}, 0.99 \% \mathrm{Mg}, 0.9 \% \mathrm{P}, 10.90-13.00 \% \mathrm{Na}, 14.0 \mathrm{mg} / \mathrm{kg}$ Co, $250 \mathrm{mg} / \mathrm{kg} \mathrm{Cu}, 9.9 \mathrm{mg} / \mathrm{kg} \mathrm{I}, 745 \mathrm{mg} / \mathrm{kg}$ Fe, $994 \mathrm{mg} / \mathrm{kg} \mathrm{Mn}, 7.5$ $\mathrm{mg} / \mathrm{kg} \mathrm{Se}, 1,100 \mathrm{mg} / \mathrm{kg} \mathrm{Zn,} \mathrm{149,000} \mathrm{IU/kg} \mathrm{vitamin} \mathrm{A,} \mathrm{23,000} \mathrm{IU} / \mathrm{kg}$ vitamin $\mathrm{D}_{3}$, and $680 \mathrm{IU} / \mathrm{kg}$ vitamin $\mathrm{E}$.

${ }^{2}$ Vitamin-mineral mix 2 contained (DM basis): 10.50-12.60\% NaCl, 9.30-11.10\% Ca, $0.91 \% \mathrm{Mg}, 0.91 \% \mathrm{P}, 8.30-9.90 \% \mathrm{Na}, 14 \mathrm{mg} / \mathrm{kg} \mathrm{Co}$, $230 \mathrm{mg} / \mathrm{kg} \mathrm{Cu}, 9.1 \mathrm{mg} / \mathrm{kg} \mathrm{I}, 685 \mathrm{mg} / \mathrm{kg} \mathrm{Fe}, 914 \mathrm{mg} / \mathrm{kg} \mathrm{Mn}, 6.9 \mathrm{mg} / \mathrm{kg}$ $\mathrm{Se}, 1,000 \mathrm{mg} / \mathrm{kg} \mathrm{Zn}, 137,000 \mathrm{IU} / \mathrm{kg}$ vitamin A, 23,000 IU $/ \mathrm{kg}$ vitamin $\mathrm{D}_{3}$, and $680 \mathrm{IU} / \mathrm{kg}$ vitamin $\mathrm{E}$. 
the fructose analog 2,5-AM and Pi. We used a short infusion period in these experiments because longterm infusion of fructose can deplete hepatic adenine nucleotide content because low concentrations of $\mathrm{Pi}$ and ATP accelerate the activity of 5 '-nucleotidase and AMP deaminase and facilitate the degradation of the adenine nucleotides beyond the stage of AMP (Woods et al., 1970; Morris et al., 1978). In addition, long-term infusion of Pi might affect phosphorus homeostasis. Because fructose rapidly decreases hepatic ATP content, we expected rapid stimulation of feed intake by fructose so we limited the infusion period to $2 \mathrm{~h}$.

Experiment 2. Four multiparous Holstein cows past peak lactation (74-81 d PP) were used in a $4 \times 4$ Latin square experiment balanced for carryover effects. All cows were fitted with a single jugular catheter as in experiment 1 . Cows were randomly assigned to tie-stalls and treatment sequences. A $2 \times 2$ factorial arrangement of treatments was used, and treatments included jugular infusions of solutions $(1 \mathrm{~L} / \mathrm{h})$ containing fructose or glucose $(0.6 \mathrm{~mol} / \mathrm{h})$ with or without phosphate $\left(\mathrm{NaH}_{2} \mathrm{PO}_{4} ; 0.3 \mathrm{~mol} / \mathrm{h}\right)$. Periods were $24 \mathrm{~h}$, beginning at the conditioned meal and included $1 \mathrm{~h}$ for infusions and $23 \mathrm{~h}$ for recovery. Cows were blocked from feed for $2 \mathrm{~h}$ before the beginning of each infusion.

Experiment 3. Four ruminally cannulated multiparous Holstein cows (15-26 d PP were used in a $4 \times 4$ Latin square experiment balanced for carryover effects. Abomasal infusion devices (L. B. Gualdron-Duarte and M. S. Allen, Michigan State University, East Lansing, unpublished data) were placed at least $3 \mathrm{~d}$ after calving, and feed intake was monitored for $2 \mathrm{~d}$ before infusion to rule out any adverse effect of the devices. Cows were randomly assigned to tiestalls and treatment sequences. A $2 \times 2$ factorial arrangement of treatments was used and treatments were the same as in experiment1. Periods were $24 \mathrm{~h}$, beginning at the conditioned meal and included a 1 -h infusion period and a 23 -h recovery period. Cows were blocked from feed for $2 \mathrm{~h}$ before the beginning of each infusion period.

\section{Data and Sample Collection}

In all the experiments infusion solutions were administered using calibrated Baxter Flo-Gard 6201 volumetric infusion pumps (Baxter Medical Products, Deerfield, IL). Feed intake was monitored by a computerized data acquisition system (Dado and Allen, 1993), and the results were validated by daily measurements of feed offered and refused. Milk yield was recorded and milk samples collected at each milking and stored with preservative at $4^{\circ} \mathrm{C}$ for component analysis. Samples of TMR and all diet ingredients were collected daily during all experiments and stored in plastic bags at $-20^{\circ} \mathrm{C}$ until processed. Blood samples were collected by venipuncture of coccygeal vessels. In experiment 1 , blood was taken before the beginning of infusions and at the end of infusion $(2 \mathrm{~h})$, whereas in experiments 2 and 3 , blood was taken before the beginning of infusion and at $30 \mathrm{~min}$ and $60 \mathrm{~min}$ after the infusion began. Blood samples were collected into 3 evacuated tubes, 2 tubes containing potassium EDTA and 1 tube containing potassium oxalate with sodium fluoride as a glycolytic inhibitor. All tubes were centrifuged at 2,000 $\times g$ for $15 \mathrm{~min}$, and plasma was harvested and stored at $-20^{\circ} \mathrm{C}$ until analysis. In the second and third experiment liver tissue was collected before the beginning of infusions, at $30 \mathrm{~min}$ into the infusion, and at the end of infusion (60 min). After local anesthetization with $2 \%$ lidocaine hydrochloride, a skin incision was performed, and the biopsy instrument (14-gauge Vet-Core biopsy needles, Global Veterinary Products, Seaforth, Australia) was inserted between the 11th and 12th ribs on a line between the olecranon and the tuber coxae on the right side. Eight samples of $\sim 20 \mathrm{mg}$ each were collected, snap-frozen in liquid nitrogen, and stored at $-80^{\circ} \mathrm{C}$ until further processing.

\section{Sample Analysis}

Feed and TMR samples were processed and analyzed for DM, NDF, CP, and starch contents. All samples were dried in a $55^{\circ} \mathrm{C}$ forced-air oven for $72 \mathrm{~h}$ and analyzed for DM concentration. Samples were then ground in a Wiley mill (1-mm screen; Arthur H. Thomas Co., Philadelphia, PA) and analyzed for NDF, CP, and starch. Concentration of NDF was determined according to Mertens (2002). Crude protein was determined according to Hach et al. (1987). Starch was gelatinized with sodium hydroxide and hydrolyzed using an enzymatic method (Karkalas, 1985); glucose was then measured using a glucose oxidase method (PGO Enzyme Product No. P7119; Sigma Chemical Co., St. Louis, $\mathrm{MO})$.

Individual milk samples were analyzed for fat, true protein, and lactose concentration by mid-infrared spectroscopy (AOAC, 1990; method 972.160) by the NorthStar Michigan Laboratory (Grand Ledge, MI). Yields of milk components were calculated using milk yield and component concentrations for each milking.

Plasma samples were analyzed in duplicate. Plasma concentration of nonesterified fatty acids (NEFA) was determined using a commercial kit [NEFA-HR (2) kit, Wako Chemicals USA Inc., Richmond, VA]. Plasma glucose concentration was analyzed using the glucose oxidase method (PGO Enzyme P7119, Sigma-Aldrich, 


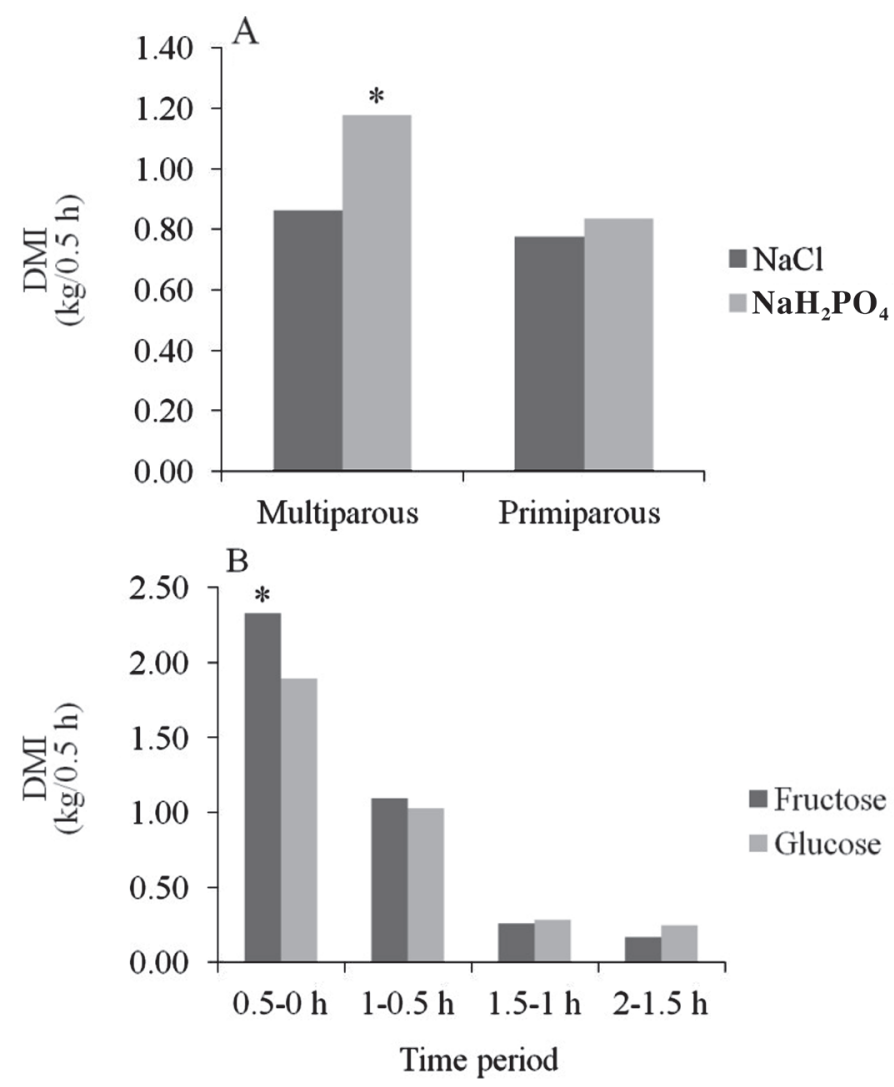

Figure 1. Statistical interactions for DMI $(\mathrm{kg} / 0.5 \mathrm{~h})$ during the 2-h jugular infusion for experiment 1. (A) Interaction between square (parity) and phosphate infusion; (B) interaction between time and fructose infusion; ${ }^{*} P \leq 0.05$.

St. Louis, MO). Plasma and liver Pi concentrations were analyzed using a commercial kit (MAK030, Sigma-Aldrich).

\section{Statistical Analysis}

In experiment 1 , DMI data for the 2-h infusion period were analyzed by repeated measures (four 0.5 -h periods within the 2-h infusion period) using the PROC MIXED of SAS (version 9.4, 2013; SAS Institute, Cary, NC). The fixed effects were time, fructose infusion, $\mathrm{Pi}$ infusion, square (parity; only in the first experiment), period, and their interactions, and cow was included as a random effect. All other data for experiment 1 and data for experiments 2 and 3 were analyzed using the fit model procedure of JMP (version 12.1, SAS Institute). For all experiments (other than DMI on experiment 1) the fixed effects were fructose infusion, $\mathrm{Pi}$ infusion, square (parity; only in the first experiment), period, and their interactions, and cow was included as a random effect. For the analysis of liver and plasma parameters, initial values before infusion treatment were used as a covariate. Main effects were declared significant at $P \leq$ 0.05 , and tendencies were declared at $P \leq 0.10$. Interactions were declared significant at $P \leq 0.10$.

\section{RESULTS AND DISCUSSION}

Phosphate infusion increased DMI by $37 \%$ for multiparous cows during the 2-h infusion period but did not affect DMI by primiparous cows (Figure 1A). The effect of Pi infusion on DMI of multiparous cows was sustained after treatment ceased, increasing DMI by $47 \%$ compared with $\mathrm{NaCl}$ infusion $(6.5$ and $4.4 \mathrm{~kg}$, respectively) over the $4 \mathrm{~h}$ since infusion began (data not shown). The Pi treatment increased daily milk yield for multiparous cows in experiment 1 by $5 \%(P=0.03)$ and tended to increase daily lactose yield by $5 \%(P=$ $0.07)$ but tended to reduce milk yield for primiparous cows by $5 \%(P=0.08)$. In both squares, $\mathrm{Pi}$ tended to increase MUN by 5\% (Table 2; Figure 2). Moreover, Pi tended to increased fat percentage by $18 \%$ for the fructose treatment only (interaction, $P=0.07$ ), and the fructose treatment increased milk protein percentage by $3 \%$ (Table 2). Fructose infusion increased DMI by $23 \%$ in the first $0.5 \mathrm{~h}$ of infusion in experiment 1 , but the effect was transient with no effect of fructose on DMI detected afterward (Figure 1B).

Table 2. Daily milk and milk component yields for experiment $1^{1}$

\begin{tabular}{|c|c|c|c|c|c|c|c|c|c|}
\hline \multirow[b]{2}{*}{ Variable } & \multicolumn{2}{|c|}{ Fructose } & \multicolumn{2}{|c|}{ Glucose } & \multicolumn{5}{|c|}{ Significance, $P$-value } \\
\hline & $\mathrm{Cl}$ & $\mathrm{Pi}$ & $\mathrm{Cl}$ & $\mathrm{Pi}$ & $\mathrm{F} / \mathrm{G}$ & $\mathrm{Cl} / \mathrm{Pi}$ & $\mathrm{F} \times \mathrm{Pi}$ & $\mathrm{F} \times$ square & $\mathrm{Pi} \times$ square \\
\hline Milk yield (kg/d) & 32.3 & 32.1 & 31.7 & 32.2 & 0.76 & 0.66 & 0.48 & 0.31 & 0.01 \\
\hline Fat $(\%)$ & 4.22 & 4.96 & 4.80 & 4.35 & 0.96 & 0.60 & 0.04 & 0.92 & 0.21 \\
\hline Fat $(\mathrm{kg} / \mathrm{d})$ & 1.40 & 1.53 & 1.51 & 1.38 & 0.81 & 0.99 & 0.07 & 0.24 & 0.89 \\
\hline Protein $(\%)$ & 3.34 & 3.35 & 3.27 & 3.23 & 0.01 & 0.57 & 0.56 & 0.97 & 0.62 \\
\hline Protein (kg/d) & 1.20 & 1.23 & 0.90 & 0.85 & 0.34 & 0.79 & 0.99 & 0.51 & 0.15 \\
\hline Lactose (\%) & 4.80 & 4.91 & 4.90 & 4.91 & 0.19 & 0.11 & 0.26 & 0.59 & 0.88 \\
\hline Lactose (kg/d) & 1.55 & 1.59 & 1.57 & 1.59 & 0.68 & 0.44 & 0.79 & 0.60 & 0.07 \\
\hline MUN (mg/dL) & 11.6 & 12.2 & 11.8 & 12.6 & 0.37 & 0.06 & 0.72 & 0.58 & 0.45 \\
\hline
\end{tabular}

${ }^{1}$ Treatments were 2 -h infusions of fructose or glucose $(\mathrm{F} / \mathrm{G} ; 0.6 \mathrm{~mol} / \mathrm{h})$ and $\mathrm{NaCl}$ or $\mathrm{NaH}_{2} \mathrm{PO}_{4}(\mathrm{Cl} / \mathrm{Pi} ; 0.3 \mathrm{~mol} / \mathrm{h})$. Square $=$ parity. 
Table 3. Plasma phosphate (Pi), nonesterified fatty acids (NEFA), and glucose concentrations at the end of the infusion period of experiment $1^{1}$

\begin{tabular}{|c|c|c|c|c|c|c|c|c|c|}
\hline Variable & \multicolumn{2}{|c|}{ Fructose } & \multicolumn{2}{|c|}{ Glucose } & \multicolumn{5}{|c|}{ Significance, $P$-value } \\
\hline $\mathrm{Pi}(\mathrm{mg} / \mathrm{dL})$ & 29.1 & 66.0 & 33.8 & 59.6 & 0.79 & $<0.0001$ & 0.11 & 0.09 & 0.08 \\
\hline NEFA $(\mu \mathrm{Eq} / \mathrm{L})$ & 326 & 316 & 176 & 270 & 0.02 & 0.30 & 0.19 & 0.72 & 0.72 \\
\hline Glucose (mg/dL) & 38.2 & 39.2 & 74.8 & 69.3 & $<0.0001$ & 0.40 & 0.22 & 0.17 & 0.36 \\
\hline
\end{tabular}

${ }^{1}$ Treatments were 2 -h infusions of fructose or glucose $(\mathrm{F} / \mathrm{G} ; 0.6 \mathrm{~mol} / \mathrm{h})$ and $\mathrm{NaCl}$ or $\mathrm{NaH}_{2} \mathrm{PO}_{4}(\mathrm{Cl} / \mathrm{Pi} ; 0.3 \mathrm{~mol} / \mathrm{h})$. Square $=$ parity.

Glucose and $\mathrm{Pi}$ infusions increased their respective concentrations in plasma compared to their control treatments as expected; glucose infusion increased plasma glucose concentration $86 \%$ compared with fructose infusion and $\mathrm{Pi}$ infusion increased plasma Pi concentration $100 \%$ compared with $\mathrm{NaCl}$ infusion (Table $3)$. Both glucose and fructose infusions reduced NEFA during the infusion period (data not shown), and although no time by treatment interaction was detected, glucose infusion decreased plasma NEFA concentration $31 \%$ compared with fructose infusion (Table 3).

Although the fructose treatment stimulated DMI compared with glucose treatment as expected, the effect was detected only during the first $0.5 \mathrm{~h}$ of infusion. The majority (50-70\%) of blood fructose in humans and rats is cleared and metabolized by the liver, but fructose is also metabolized by other tissues including intestine, testis, kidney, skeletal muscle, adipose, and brain (Mayes, 1993; Douard and Ferraris, 2008). It is possible that, during the first $0.5 \mathrm{~h}$, most of the fructose was cleared by the liver, sequestering $\mathrm{Pi}$ and decreasing ATP production, but as liver fructose concentration increased, the rate of fructose clearance from the blood was reduced, enabling greater clearance by other tissues. The greater reduction in plasma NEFA concentration for the glucose infusion compared with fructose

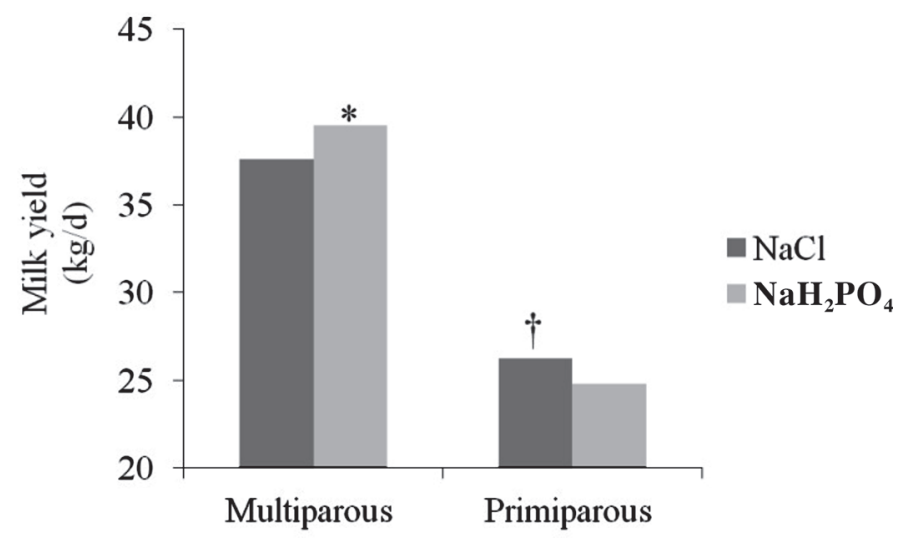

Figure 2. Statistical interaction between phosphate infusion and square (parity) for daily milk yield $(\mathrm{kg} / \mathrm{d})$ in the first experiment; ${ }^{*} P$ $=0.03, \dagger P=0.08$. infusion might have masked the stimulation of DMI by fructose over the first $0.5 \mathrm{~h}$ because a greater reduction in plasma NEFA concentration following feeding caused a reduction in hepatic acetyl CoA content and was positively related to DMI among cows in the PP period, likely by reducing hepatic oxidation (Piantoni et al., 2015).

In contrast, the stimulation of DMI by Pi infusion for multiparous cows was unexpected and may have occurred because it increased daily milk yield for these cows clearing fuels from the blood. Because phosphorus requirement is related to the production level of the cow (NRC, 2001) and the multiparous cows produced $51 \%$ more milk than the primiparous cows (38.6 and $25.5 \mathrm{~kg} / \mathrm{d}$, respectively), the multiparous cows may have had a higher requirement for $\mathrm{Pi}$ and thus benefited from the Pi infusion. The lack of effect of $\mathrm{Pi}$ infusion on DMI of primiparous cows might be because it tended to reduce milk yield compared to control.

The unexpected effect of $\mathrm{Pi}$ on intake in experiment 1 raised the following questions: Was this a positive effect of $\mathrm{Pi}$ or a negative effect of $\mathrm{NaCl}$, and was $\mathrm{Pi}$ affecting intake through mechanisms related to hepatic activity? To answer these questions, we conducted experiment 2 , in which the control treatment for $\mathrm{Pi}$ was no infusion (not $\mathrm{NaCl}$ ) and liver samples were taken to evaluate effects of treatment on hepatic Pi content. Generally, fructose had no effect on DMI throughout experiment 2 , but Pi increased DMI by $28 \%$ at $0.5 \mathrm{~h}$ and tended to increase DMI by $24 \%$ at $1 \mathrm{~h}$ and $37 \%$ at $2 \mathrm{~h}$ after the beginning of infusion (Table 4). After $8 \mathrm{~h}, \mathrm{Pi}$ increased intake by $43 \%$ only with the fructose treatment (interaction, $P=0.06)$.

Treatments did not affect yields of milk or milk components in experiment 2 (Table 5). However, Pi treatment interacted with fructose treatment to affect milk fat concentration; Pi reduced milk fat concentration by $17 \%$ when infused with fructose, but it did not affect milk fat concentration when infused with glucose. Consistent with our expectations, glucose treatment increased plasma glucose concentration by $32 \%$ at 30 min and $43 \%$ at 60 min after the start of infusion compared with fructose treatment (Table 6). Similarly, Pi treatment increased plasma $\mathrm{Pi}$ concentration $173 \%$ at 
Table 4. Dry matter intake $(\mathrm{kg})$ during the infusion and postinfusion period of experiment $2^{1}$

\begin{tabular}{|c|c|c|c|c|c|c|c|}
\hline \multirow{2}{*}{$\begin{array}{l}\text { Time since } \\
\text { infusion start (h) }\end{array}$} & \multicolumn{2}{|c|}{ Fructose } & \multicolumn{2}{|c|}{ Glucose } & \multicolumn{3}{|c|}{ Significance, $P$-value } \\
\hline & $\mathrm{XPi}$ & $\mathrm{Pi}$ & XPi & $\mathrm{Pi}$ & $\mathrm{F} / \mathrm{G}$ & $\mathrm{XPi} / \mathrm{Pi}$ & $\mathrm{F} \times \mathrm{Pi}$ \\
\hline 0.5 & 1.80 & 2.73 & 2.16 & 2.35 & 0.96 & 0.05 & 0.15 \\
\hline 1 & 2.33 & 3.40 & 2.90 & 3.10 & 0.69 & 0.10 & 0.24 \\
\hline 2 & 3.46 & 5.80 & 4.40 & 5.02 & 0.92 & 0.10 & 0.31 \\
\hline 4 & 6.16 & 8.30 & 8.02 & 7.32 & 0.73 & 0.58 & 0.29 \\
\hline 8 & 11.4 & 16.3 & 14.2 & 14.1 & 0.79 & 0.06 & 0.06 \\
\hline 24 & 24.6 & 26.8 & 25.5 & 25.6 & 0.86 & 0.17 & 0.18 \\
\hline
\end{tabular}

60 min after the start of infusion but did not increase hepatic Pi concentration.

Failure of fructose to increase DMI of cows in experiment 2 that were just past peak lactation is consistent with a signal from gut distention dominating control of feed intake during this period with diminished signals from hepatic oxidation (Allen, 1996; Allen et al., 2009). Increased DMI by $\mathrm{Pi}$ treatment in this experiment indicates that intravenous infusion of $\mathrm{Pi}$ increases intake rather than the $\mathrm{NaCl}$ infusion reducing intake, answering the question raised from experiment 1. Moreover, intravenously infused $\mathrm{Pi}$ failed to increase hepatic Pi content and increased DMI in mid-lactation cows, suggesting it increases intake through mechanisms unrelated to hepatic oxidation and energy charge. Furthermore, the increase in DMI was not related to greater clearance of fuels from the blood by the mammary gland because yields of milk and milk components were not affected by treatment. Because intravenous infusion of $\mathrm{Pi}$ failed to increase hepatic Pi content, a different approach was required to understand the effect of hepatic $\mathrm{Pi}$ on intake and treatments were infused directly to the abomasum in experiment 3 .

In experiment 3 , interactions of main effects of treatment were detected at $2 \mathrm{~h}(P=0.03), 4 \mathrm{~h}(P=0.003)$, and $8 \mathrm{~h}(P=0.008)$ after the start of the 1 -h infusion.
The fructose treatment increased DMI by $4 \mathrm{~h}$ after the start of infusion and Pi decreased DMI by $\sim 33 \%$ only for the fructose treatment at 2, 4, and $8 \mathrm{~h}$ after the start of infusion (Table 7). Treatments did not affect yields of milk or milk components, but $\mathrm{Pi}$ increased MUN by $10 \%$ ( $P=0.01$, Table 8$)$. Glucose compared with fructose treatment tended to increase plasma glucose concentration by $5 \%(P=0.06)$ at $30 \mathrm{~min}$, but the effect diminished $(P=0.15)$ by 60 min after the start of infusion (Table 9). The Pi treatment increased plasma $\mathrm{Pi}$ concentration at $60 \mathrm{~min}$ after the start of infusion by $11 \%(P=0.04)$ compared to the $\mathrm{NaCl}$ control treatment. The Pi treatment increased hepatic Pi content at 30 min $(P=0.002)$, but the increase was greater when infused with glucose than with fructose $(P=0.07)$, and treatment had no effect on hepatic Pi content at $60 \mathrm{~min}$. This finding suggests that fructose probably sequestered the Pi taken up by the liver and possibly saturated because plasma Pi was only increased $60 \mathrm{~min}$ after Pi infusion begun.

Our primary hypotheses were that fructose increases intake by sequestering $\mathrm{Pi}$ and that $\mathrm{Pi}$ infusion will reduce the effect of fructose. The results of experiment 3 fit these hypotheses, are consistent with hepatic ATP concentration affecting DMI, and present another level by which hepatic energy charge controls and af-

Table 5. Daily milk and milk component yields for experiment $2^{1}$

\begin{tabular}{|c|c|c|c|c|c|c|c|}
\hline \multirow[b]{2}{*}{ Variable } & \multicolumn{2}{|c|}{ Fructose } & \multicolumn{2}{|c|}{ Glucose } & \multicolumn{3}{|c|}{ Significance, $P$-value } \\
\hline & XPi & $\mathrm{Pi}$ & $\mathrm{XPi}$ & $\mathrm{Pi}$ & $\mathrm{F} / \mathrm{G}$ & $\mathrm{XPi} / \mathrm{Pi}$ & $\mathrm{F} \times \mathrm{Pi}$ \\
\hline Milk yield $(\mathrm{kg} / \mathrm{d})$ & 50.4 & 53.1 & 52.8 & 50.7 & 0.99 & 0.88 & 0.27 \\
\hline Fat $(\%)$ & 3.58 & 2.98 & 3.23 & 3.34 & 0.95 & 0.13 & 0.05 \\
\hline Fat $(\mathrm{kg} / \mathrm{d})$ & 1.81 & 1.58 & 1.71 & 1.68 & 0.95 & 0.23 & 0.34 \\
\hline Protein (\%) & 2.61 & 2.68 & 2.63 & 2.81 & 0.40 & 0.14 & 0.53 \\
\hline Protein $(\mathrm{kg} / \mathrm{d})$ & 1.32 & 1.43 & 1.39 & 1.41 & 0.51 & 0.15 & 0.35 \\
\hline Lactose $(\%)$ & 5.00 & 5.03 & 5.06 & 5.00 & 0.65 & 0.65 & 0.27 \\
\hline Lactose $(\mathrm{kg} / \mathrm{d})$ & 2.52 & 2.67 & 2.67 & 2.54 & 0.91 & 0.92 & 0.22 \\
\hline MUN (mg/dL) & 15.6 & 15.1 & 14.4 & 14.8 & 0.31 & 0.92 & 0.52 \\
\hline
\end{tabular}

${ }^{1}$ Treatments were 1-h infusions of fructose or glucose $(\mathrm{F} / \mathrm{G} ; 0.6 \mathrm{~mol} / \mathrm{h})$ and with $\mathrm{NaH}_{2} \mathrm{PO}_{4}(\mathrm{Pi}, 0.3 \mathrm{~mol} / \mathrm{h})$ or without (XPi). 
Table 6. Plasma and liver content during the infusion period of experiment $2^{1}$

\begin{tabular}{|c|c|c|c|c|c|c|c|c|}
\hline Variable & $\begin{array}{l}\text { Time into } \\
\text { infusion (min) }\end{array}$ & \multicolumn{2}{|c|}{ Fructose } & \multicolumn{2}{|c|}{ Glucose } & \multicolumn{3}{|c|}{ Significance, $P$-value } \\
\hline Plasma Pi (mg/dL) & 30 & 11.3 & 21.7 & 12.9 & 14.9 & 0.40 & 0.15 & 0.22 \\
\hline \multirow{3}{*}{$\begin{array}{l}\text { Plasma nonesterified fatty } \\
\text { acids }(\mu \mathrm{Eq} / \mathrm{L}) \\
\text { Plasma glucose }(\mathrm{mg} / \mathrm{dL})\end{array}$} & 30 & 298 & 230 & 207 & 213 & 0.28 & 0.47 & 0.40 \\
\hline & 60 & 189 & 230 & 167 & 133 & 0.30 & 0.94 & 0.50 \\
\hline & 30 & 62.6 & 60.7 & 82.3 & 80.0 & 0.007 & 0.67 & 0.95 \\
\hline Liver Pi $(\mu \mathrm{mol} / \mathrm{g})$ & 60 & 10.4 & 12.8 & 11.9 & 10.6 & 0.94 & 0.88 & 0.68 \\
\hline
\end{tabular}

${ }^{1}$ Treatments were 1-h infusions of fructose or glucose $(\mathrm{F} / \mathrm{G} ; 0.6 \mathrm{~mol} / \mathrm{h})$ and with $\mathrm{NaH}_{2} \mathrm{PO}_{4}(\mathrm{Pi}, 0.3 \mathrm{~mol} / \mathrm{h})$ or without $(\mathrm{XPi})$.

Table 7. Dry matter intake $(\mathrm{kg})$ during the infusion and postinfusion period of experiment $3^{1}$

\begin{tabular}{|c|c|c|c|c|c|c|c|}
\hline \multirow{2}{*}{$\begin{array}{l}\text { Time into } \\
\text { infusion (h) }\end{array}$} & \multicolumn{2}{|c|}{ Fructose } & \multicolumn{2}{|c|}{ Glucose } & \multicolumn{3}{|c|}{ Significance, $P$-value } \\
\hline & $\mathrm{Cl}$ & $\mathrm{Pi}$ & $\mathrm{Cl}$ & $\mathrm{Pi}$ & $\mathrm{F} / \mathrm{G}$ & $\mathrm{Cl} / \mathrm{Pi}$ & $\mathrm{F} \times \mathrm{Pi}$ \\
\hline 0.5 & 1.93 & 1.35 & 1.67 & 1.48 & 0.67 & 0.05 & 0.26 \\
\hline 1 & 1.96 & 1.54 & 1.78 & 1.69 & 0.92 & 0.18 & 0.35 \\
\hline 2 & $3.20^{\mathrm{a}}$ & $2.16^{\mathrm{b}}$ & $2.65^{\mathrm{ab}}$ & $3.08^{\mathrm{a}}$ & 0.49 & 0.28 & 0.03 \\
\hline 4 & $5.14^{\mathrm{a}}$ & $3.50^{\mathrm{b}}$ & $4.00^{\mathrm{b}}$ & $3.59^{\mathrm{b}}$ & 0.05 & 0.03 & 0.003 \\
\hline 8 & $7.93^{\mathrm{a}}$ & $5.19^{\mathrm{c}}$ & $6.19^{\mathrm{bc}}$ & $7.40^{\mathrm{ab}}$ & 0.66 & 0.18 & 0.008 \\
\hline 24 & 16.5 & 14.5 & 15.1 & 15.8 & 0.99 & 0.50 & 0.20 \\
\hline
\end{tabular}

${ }^{\mathrm{a}-\mathrm{c}}$ Means within a row with different superscripts differ $(P<0.05)$.

${ }^{1}$ Treatments were 1 -h infusions of fructose or glucose $(\mathrm{F} / \mathrm{G} ; 0.6 \mathrm{~mol} / \mathrm{h})$ and $\mathrm{NaCl}$ or $\mathrm{NaH}_{2} \mathrm{PO}_{4}(\mathrm{Cl} / \mathrm{Pi} ; 0.3$ $\mathrm{mol} / \mathrm{h})$.

Table 8. Daily milk and milk component yields for experiment $3^{1}$

\begin{tabular}{|c|c|c|c|c|c|c|c|}
\hline \multirow[b]{2}{*}{ Variable } & \multicolumn{2}{|c|}{ Fructose } & \multicolumn{2}{|c|}{ Glucose } & \multicolumn{3}{|c|}{ Significance, $P$-value } \\
\hline & $\mathrm{Cl}$ & $\mathrm{Pi}$ & $\mathrm{Cl}$ & $\mathrm{Pi}$ & $\mathrm{F} / \mathrm{G}$ & $\mathrm{Cl} / \mathrm{Pi}$ & $\mathrm{F} \times \mathrm{Pi}$ \\
\hline Milk yield $(\mathrm{kg} / \mathrm{d})$ & 34.7 & 33.5 & 33.4 & 34.2 & 0.73 & 0.81 & 0.32 \\
\hline Fat $(\%)$ & 3.79 & 3.96 & 3.85 & 3.95 & 0.88 & 0.50 & 0.85 \\
\hline Fat $(\mathrm{kg} / \mathrm{d})$ & 1.32 & 1.33 & 1.27 & 1.36 & 0.87 & 0.47 & 0.49 \\
\hline Protein (\%) & 2.48 & 2.42 & 2.43 & 2.44 & 0.47 & 0.26 & 0.11 \\
\hline Protein $(\mathrm{kg} / \mathrm{d})$ & 0.86 & 0.81 & 0.81 & 0.83 & 0.54 & 0.63 & 0.22 \\
\hline Lactose $(\%)$ & 4.80 & 4.78 & 4.80 & 4.81 & 0.62 & 0.70 & 0.62 \\
\hline Lactose $(\mathrm{kg} / \mathrm{d})$ & 1.67 & 1.61 & 1.60 & 1.64 & 0.76 & 0.79 & 0.34 \\
\hline MUN (mg/dL) & 12.3 & 13.7 & 13.0 & 14.2 & 0.14 & 0.01 & 0.72 \\
\hline
\end{tabular}

${ }^{1}$ Treatments were 1-h infusions of fructose or glucose $(\mathrm{F} / \mathrm{G} ; 0.6 \mathrm{~mol} / \mathrm{h})$ and $\mathrm{NaCl}$ or $\mathrm{NaH}_{2} \mathrm{PO}_{4}(\mathrm{Cl} / \mathrm{Pi} ; 0.3$ $\mathrm{mol} / \mathrm{h})$.

Table 9. Plasma and liver content during the infusion period of experiment $3^{1}$

\begin{tabular}{|c|c|c|c|c|c|c|c|c|}
\hline Variable & $\begin{array}{l}\text { Time into } \\
\text { infusion (min) }\end{array}$ & \multicolumn{2}{|c|}{ Fructose } & \multicolumn{2}{|c|}{ Glucose } & \multicolumn{3}{|c|}{ Significance, $P$-value } \\
\hline Plasma Pi (mg/dL) & 60 & 22.1 & 24.7 & 21.4 & 23.6 & 0.35 & 0.04 & 0.82 \\
\hline \multirow{2}{*}{$\begin{array}{l}\text { Plasma nonesterified fatty } \\
\text { acids }(\mu \mathrm{Eq} / \mathrm{L})\end{array}$} & 30 & 595 & 580 & 677 & 563 & 0.67 & 0.46 & 0.52 \\
\hline & 60 & 484 & 460 & 658 & 583 & 0.32 & 0.74 & 0.86 \\
\hline Plasma glucose (mg/dL) & 30 & 47.9 & 46.2 & 49.9 & 49.1 & 0.06 & 0.26 & 0.69 \\
\hline & 60 & 7.10 & 7.60 & 6.68 & 9.85 & 0.69 & 0.40 & 0.54 \\
\hline
\end{tabular}

${ }_{\mathrm{a}, \mathrm{b}}$ Means within a row with different superscripts differ $(P<0.05)$.

${ }^{1}$ Treatments were 1-h infusions of fructose or glucose $(\mathrm{F} / \mathrm{G} ; 0.6 \mathrm{~mol} / \mathrm{h})$ and $\mathrm{NaCl}$ or $\mathrm{NaH}_{2} \mathrm{PO}_{4}(\mathrm{Cl} / \mathrm{Pi} ; 0.3 \mathrm{~mol} / \mathrm{h})$. 
fects feed intake in dairy cows. That Pi reduces DMI when infused abomasally and increases DMI when infused intravenously suggests that Pi affects DMI by 2 independent mechanisms; abomasal infusion probably affects DMI through a liver-related mechanism, and intravenous infusion likely affects DMI by a liverindependent mechanism. Higher producing cows may have a higher metabolic requirement for phosphorus than what is currently provided in rations, and the fact that increasing the phosphorous content in diets has no effect on DMI (Peterson et al., 2005; Grünberg et al., 2011; Puggaard et al., 2011) might be because of the hypophagic effect of $\mathrm{Pi}$ through a mechanism related to hepatic oxidation. This hypothesis needs to be further verified in longer-term experiments to understand whether competing mechanisms exist for effects of $\mathrm{Pi}$ on DMI, which would make it difficult to determine the true $\mathrm{P}$ requirements of dairy cows.

Fructose infusion increased intake when infused to fresh cows, abomasally or intravenously. Because fructose is rapidly fermented in the rumen, mainly to lactate and butyrate (Golder et al., 2012), feeding fructose is not expected to increase DMI. However, sorbitol can be metabolized to fructose in the liver of nonruminants and ruminants (Blakley, 1951; Shaw, 1974; Mayes, 1993). Part of the sorbitol consumed by ruminants may escape ruminal fermentation; for example, in sheep as much as 5 to $7 \%$ of the sorbitol escaped ruminal metabolism (Geay et al., 1992). Accordingly, sorbitol feeding may potentially increase DMI in fresh cows.

The results of this research demonstrate the complex mechanisms that control feed intake in dairy cows, provide evidence for an effect of ATP production on DMI, and suggest that $\mathrm{Pi}$ affects intake by 2 competing mechanisms.

\section{ACKNOWLEDGMENTS}

We acknowledge Michigan AgBioResearch (East Lansing, MI) for partial financial support of this research and BARD, the United States-Israel Binational Agricultural Research and Development Fund, VaadiaBARD Postdoctoral Fellowship Award No. FI-5062014. We also thank J. Liesman for statistical advice; Mark Friedman and Michael Tordoff (both from Monell Chemical Senses Center, Philadelphia, PA) for related discussions; and D. G. Main, R. A. Longuski, L. B. Gualdron-Duarte, R.I. Albornoz, K. M. Kennedy, G. Maldini, D. Oliveira, and R. West (all from Michigan State University) as well as the staff of the Michigan State University Dairy Cattle Field Laboratory (East Lansing) for their assistance in this experiment.

\section{REFERENCES}

Abdelmalek, M. F., M. Lazo, A. Horska, S. Bonekamp, E. W. Lipkin, A. Balasubramanyam, J. P. Bantle, R. J. Johnson, A. M. Diehl, J. M. Clark, and the Fatty Liver Subgroup of the Look AHEAD Research Group. 2012. Higher dietary fructose is associated with impaired hepatic adenosine triphosphate homeostasis in obese individuals with type 2 diabetes. Hepatology 56:952-960.

Allen, M. S. 1996. Physical constraints on voluntary intake of forages by ruminants. J. Anim. Sci. 74:3063-3075.

Allen, M. S. 2014. Drives and limits to feed intake in ruminants. Anim. Prod. Sci. 54:1513-1524.

Allen, M. S., B. J. Bradford, and M. Oba. 2009. Board invited review: The hepatic oxidation theory of the control of feed intake and its application to ruminants. J. Anim. Sci. 87:3317-3334.

AOAC. 1990. Official Methods of Analysis. Vol. 2. 15th ed. Association Official Analytical Chemists, Arlington, VA.

Blakley, R. L. 1951. The metabolism and antiketogenic effects of sorbitol. Sorbitol dehydrogenase. Biochem. J. 49:257-271.

Dado, R. G., and M. S. Allen. 1993. Continuous computer acquisition of feed and water intakes, chewing, reticular motility, and ruminal pH of cattle. J. Dairy Sci. 76:1589-1600.

Derno, M., G. Nurnberg, P. Schon, A. Schwarm, M. Rontgen, H. M. Hammon, C. C. Metges, R. M. Bruckmaier, and B. Kuhla. 2013. Short-term feed intake is regulated by macronutrient oxidation in lactating Holstein cows. J. Dairy Sci. 96:971-980.

Douard, V., and R. P. Ferraris. 2008. Regulation of the fructose transporter GLUT5 in health and disease. Am. J. Physiol. Endocrinol. Metab. 295:E227-E237.

Friedman, M. I., R. B. Harris, H. Ji, I. Ramirez, and M. G. Tordoff. 1999. Fatty acid oxidation affects food intake by altering hepatic energy status. Am. J. Physiol. 276:R1046-R1053.

Geay, Y., E. Richet, S. Ba, and P. Thivend. 1992. Effects of feeding sorbitol associated with different sources and amounts of nitrogen on growth, digestion and metabolism in young bulls. Anim. Feed Sci. Technol. 36:255-273.

Golder, H. M., P. Celi, A. R. Rabiee, C. Heuer, E. Bramley, D. W Miller, R. King, and I. J. Lean. 2012. Effects of grain, fructose, and histidine on ruminal $\mathrm{pH}$ and fermentation products during an induced subacute acidosis protocol. J. Dairy Sci. 95:1971-1982.

Grünberg, W., S. S. Donkin, and P. D. Constable. 2011. Periparturient effects of feeding a low dietary cation-anion difference diet on acidbase, calcium, and phosphorus homeostasis and on intravenous glucose tolerance test in high-producing dairy cows. J. Dairy Sci. 94:727-745.

Hach, C. C., B. K. Bowden, A. B. Kopelove, and S. V. Brayton. 1987. More powerful peroxide Kjeldahl digestion method. J. Assoc. Off. Anal. Chem. 70:783-787.

Ingvartsen, K. L., and J. B. Andersen. 2000. Integration of metabolism and intake regulation: A review focusing on periparturient animals. J. Dairy Sci. 83:1573-1597.

Karkalas, J. 1985. An improved enzymic method for the determination of native and modified starch. J. Sci. Food Agric. 36:1019-1027.

Kjerulf-Jensen, K. 1942. The phosphate esters formed in the liver tissue of rats and rabbits during assimilation of hexoses and glycerol. Acta Physiol. Scand. 4:249-258.

Koch, J. E., H. Ji, M. D. Osbakken, and M. I. Friedman. 1998. Temporal relationships between eating behavior and liver adenine nucleotides in rats treated with 2,5-AM. Am. J. Physiol. 274:R610-R617.

Langhans, W. 1996. Role of the liver in the metabolic control of eating: What we know - and what we do not know. Neurosci. Biobehav. Rev. 20:145-153.

Martineau, R., D. R. Ouellet, E. Kebreab, and H. Lapierre. 2016. Casein infusion rate influences feed intake differently depending on metabolizable protein balance in dairy cows: A multilevel metaanalysis. J. Dairy Sci. 99:2748-2761.

Mayes, P. A. 1993. Intermediary metabolism of fructose. Am. J. Clin. Nutr. 58:754S-765S. 
Mertens, D. R. 2002. Gravimetric determination of amylase-treated neutral detergent fiber in feeds with refluxing in beakers or crucibles: Collaborative study. J. AOAC Int. 85:1217-1240.

Morris, R. C., K. Nigon, and E. B. Reed. 1978. Evidence that the severity of depletion of inorganic phosphate determines the severity of the disturbance of adenine nucleotide metabolism in the liver and renal cortex of the fructose-loaded rat. J. Clin. Invest. 61:209-220.

Novin, D., L. O'Farrell, A. Acevedo-Cruz, and P. J. Geiselman. 1991. The metabolic basis for "paradoxical" and normal feeding. Brain Res. Bull. 27:435-438.

NRC. 2001. Nutrient Requirements of Dairy Cattle. 7th ed. Natl. Acad. Press, Washington, DC.

Peterson, A. B., M. W. Orth, J. P. Goff, and D. K. Beede. 2005. Periparturient responses of multiparous Holstein cows fed different dietary phosphorus concentrations prepartum. J. Dairy Sci. 88:3582-3594.

Piantoni, P., C. M. Ylioja, and M. S. Allen. 2015. Feed intake is related to changes in plasma nonesterified fatty acid concentration and hepatic acetyl CoA content following feeding in lactating dairy cows. J. Dairy Sci. 98:6839-6847.

Puggaard, L., N. B. Kristensen, and J. Sehested. 2011. Effect of decreasing dietary phosphorus supply on net recycling of inorganic phosphate in lactating dairy cows. J. Dairy Sci. 94:1420-1429.
Rawson, N. E., H. Blum, M. D. Osbakken, and M. I. Friedman. 1994. Hepatic phosphate trapping, decreased ATP, and increased feeding after 2,5-anhydro-D-mannitol. Am. J. Physiol. 266:R112-R117.

Rawson, N. E., and M. I. Friedman. 1994. Phosphate loading prevents the decrease in ATP and increase in food intake produced by 2,5-anhydro-D-mannitol. Am. J. Physiol. 266:R1792-R1796.

Schäff, C., D. Albrecht, H. M. Hammon, M. Röntgen, C. C. Metges, and B. Kuhla. 2012. A longitudinal proteomic approach to investigate liver metabolism in periparturient dairy cows with different body fat mobilization. Pages 145-147 in Farm Animal Proteomics. Wageningen Academic Publishers, Wageningen, the Netherlands.

Shaw, F. D. 1974. Sorbitol dehydrogenase in the diagnosis of liver disease of ruminants. Aust. Vet. J. 50:277-278.

Stangassinger, M., and D. Giesecke. 1986. Splanchnic metabolism of glucose and related energy substrates. Pages 347-366 in Control of Digestion and Metabolism in Ruminants. L. P. Milligan, W. L. Grovum, and A. Dobson, ed. Prentice Hall, Englewood Cliffs, NJ.

Tordoff, M. G., R. Rafka, M. J. DiNovi, and M. I. Friedman. 1988. 2,5-Anhydro-D-mannitol: A fructose analogue that increases food intake in rats. Am. J. Physiol. 254:R150-R153.

Woods, H. F., L. V. Eggleston, and H. A. Krebs. 1970. The cause of hepatic accumulation of fructose 1-phosphate on fructose loading. Biochem. J. 119:501-510. 